\title{
Danuta Milaszewicz*
}

Uniwersytet Szczeciński

Krzysztof Kielec $^{* *}$

\section{POWSTANIE EUROPEJSKIEJ UNII WALUTOWEJ JAKO OPTYMALNEGO OBSZARU WALUTOWEGO}

\section{STRESZCZENIE}

W artykule przedstawiono warunki powstania i rozwój teorii optymalnego obszaru walutowego (TOOW) oraz wskazywane przez tę teorię ekonomiczne kryteria, które powinien spełnić taki obszar. Głównym celem opracowania jest próba oceny adaptacji dorobku myśli ekonomicznej w temacie optymalnego obszaru walutowego podczas realizacji planów dotyczących powstania unii walutowej w Europie powołanej do życia w 1999 roku. Wyniki tej oceny sugerują, iż powodem utworzenia europejskiej unii walutowej były przede wszystkim względy polityczne, a nie ekonomiczne.

Słowa kluczowe: optymalny obszar walutowy, kryteria, strefa euro

\section{Wprowadzenie}

Pierre Werner, luksemburski premier i minister finansów, przedstawił w 1970 roku pierwszy plan powołania unii gospodarczo-walutowej w Europie. Odejście od syste-

* Adres e-mail: dmilasz@wneiz.pl.

** Adres e-mail: krzysztof.kielec@wp.pl. 
mu z Bretton Woods, czego konsekwencją było upłynnienie kursów walutowych, oraz kryzys naftowy wzmogły presję inflacyjną, która uniemożliwiła stabilizację kursów wymiany i w konsekwencji projekt ten nie został urzeczywistniony. Jacques Delors, przewodniczący Komisji Europejskiej, przywrócił realizację tej idei, uwzględniając również powołanie wspólnego banku centralnego. W 1989 roku opublikowano raport Delorsa zakładający utworzenie europejskiej unii walutowej, co zostało zmaterializowane w 1999 roku.

Równolegle do działań politycznych toczyła się rozprawa ekonomiczna dotycząca uwarunkowań pozwalających na optymalne funkcjonowanie unii walutowej. Niniejszy artykuł jest próbą oceny adaptacji dorobku myśli ekonomicznej w temacie optymalnego obszaru walutowego podczas realizacji ówczesnych planów politycznych dotyczących utworzenia unii walutowej w Europie.

\section{Teoria optymalnego obszaru walutowego}

Optymalnym obszarem walutowym (OOW) jest terytorium, na którym polityka fiskalno-monetarna i zewnętrzny, płynny kurs walutowy mogą być użyte dla zapewnienia optymalnych rozwiązań w zakresie: utrzymania pełnego zatrudnienia, równowagi bilansu płatniczego oraz stabilnego poziomu cen wewnętrznych (McKinnon, 1963). Rozważania nad tym zagadnieniem zostały zainicjowane w 1961 roku przez kanadyjskiego ekonomistę Roberta Alexandra Mundella artykułem w „The American Economic Review" podczas dyskusji nad wadami systemu z Bretton Woods, które doprowadziły do jego upadku.

Debata nad tym problemem oraz zaletami sztywnego i płynnego kursu walutowego, do której włączyli się inni ekonomiści, uważana jest za początek TOOW. Teoria ta precyzuje kryteria, które muszą zostać spełnione na obszarze, by bez wykorzystywania atrybutów polityki fiskalnej lub monetarnej determinowały dostosowanie się warunków gospodarczych do poziomów optymalnych kategorii ekonomicznych (jak presja inflacyjna, stopa bezrobocia, bilans płatniczy) w warunkach braku równowagi popytu i podaży (szczególnie uwzględniając szoki asymetryczne).

W ramach tej dyskusji Mundell przedstawił dwa modele wymiany handlowej pomiędzy dwoma krajami ze sztywnymi kursami walut, które są w równowadze zewnętrznej (zrównoważony bilans płatniczy) i wewnętrznej (niska stopa bezrobocia oraz niska stopa inflacji). Pierwszy model, z użyciem odrębnych walut, pokazuje 
skutki silnego spadku popytu w pierwszym kraju i jego wzrostu w drugim kraju. Aktywna polityka monetarna w celu ograniczenia inflacji prowadzi do dewaluacji wewnętrznej w kraju dotkniętym spadkiem popytu i implikuje w konsekwencji recesję na rynku globalnym z powodu pogorszenia się terms of trade. Drugi model, z wykorzystaniem wspólnej waluty, przedstawia analogicznie zmiany popytu w obu krajach. Zastosowanie polityki monetarnej zwiększy podaż pieniądza w kraju dotkniętym spadkiem popytu i pomoże w walce $\mathrm{z}$ bezrobociem, lecz równocześnie zwiększy presję inflacyjną w drugim kraju. Mundell wnioskuje, iż aktywna polityka monetarna na obszarze ze wspólną walutą nie może w tym samym czasie zapobiegać bezrobociu i inflacji, więc wskazuje jako rozwiązanie możliwość przepływu czynników produkcji. Swoboda przepływu czynników produkcji umożliwia ich optymalną alokację na obszarze wymiany handlowej i wywołuje procesy doprowadzające do równowagi płatniczej. Mundell (1961) określił czynniki produkcji jako pracę i kapitał, twierdząc, że dla właściwego funkcjonowania OOW należy zapewnić spełnienie jednego z następujących kryteriów:

a) maksymalną elastyczność rynków pracy pozwalającą na migrację pracowników na obszarze walutowym;

b) swobodę przepływu kapitału wskutek liberalizacji i ujednolicenia jurysdykcji na obszarze walutowym.

Ronald Ian McKinnon (1963), kolejny kanadyjski ekonomista, zwrócił uwagę na brak możliwości szybkiego dostosowania się gospodarki obszaru walutowego za pomocą mobilnych czynników produkcji z powodu kosztów migracji, różnic kulturowych oraz braku czasu na wdrożenie inwestycji kapitałowych. W związku z tym zaproponował, by obszar walutowy składał się z gospodarek otwartych, w których w przypadku zakłóceń równowagi rynkowej możliwa będzie do zastosowania właściwa polityka monetarna i fiskalna w celu zmniejszenia importu na obszarze walutowym i przesunięcia czynników produkcji do gałęzi gospodarki wytwarzającej dobra eksportowe.

McKinnon wskazał ponadto w kontekście obszaru walutowego na wpływ kursu walutowego na perspektywy makroekonomiczne w gospodarkach o różnym stopniu otwartości na zewnętrzną wymianę handlową. W gospodarkach, gdzie wartość eksportu i importu jest relatywnie wysoka w stosunku do wartości rynku wewnętrznego, odchylenie kursu walut może mieć znaczący wpływ na poziom wartości rynku wewnętrznego i należy stosować w nich stałe kursy walutowe. Z kolei gospodarki 
relatywnie zamknięte odczują taką zmianę w mniejszym stopniu, co uzasadnia zastosowanie zmiennego kursu walutowego (McKinnon, 1963).

Peter Kenen (1969, s. 41-60), amerykański ekonomista, podkreślił istotę struktury gospodarczej w ramach TOOW. Gospodarki tworzące obszar walutowy powinny być możliwie jak najbardziej zdywersyfikowane i zbliżone strukturalnie, co zmniejsza prawdopodobieństwo powstania newralgicznych gałęzi, których kryzys skutkowałby problemami w skali makroekonomicznej. Jego zdaniem dywersyfikacja wpływa również na stabilizację kursów walutowych. Kenen zwraca szczególną uwagę na możliwości kapitału finansowego, który może reagować najszybciej poprzez transfery w miejsca objęte kryzysem. Uważa także, że polityka fiskalna i monetarna powinny być spójne i prowadzone dla całego obszaru walutowego, a z budżetu obszaru walutowego dopuszczalne są interwencje w miejscach objętych kryzysem. Wspólna waluta dla całego obszaru stabilizowałaby w większym stopniu poziom kursu walutowego, zapewniając równowagę w handlu zagranicznym (Kenen, 1969, s. 41-60).

W 1962 roku James C. Ingram (1962, s. 195) zwrócił uwagę na rolę integracji finansowej, która może implikować płynne dostosowania się kursów walutowych i stóp procentowych w długim okresie na OOW, co ułatwi finansowanie deficytów sektora prywatnego i publicznego. Odnosząc się do rozważań Mundella, podkreślał on, iż Mundell kładzie większy nacisk na mobilność pracowników, podczas gdy to przepływ kapitału na wolnym rynku jest szybszą i skuteczniejszą metodą ograniczającą skutki nierównowagi popytu i podaży. Ingram (1962, s. 198) wskazywał również, że kapitał powinien finansować inwestycje zwiększające wydajność lub zdolność produkcyjną.

Kolejne kryterium OOW - podobieństwa stopy inflacji - zostało sformułowane w następnych latach. Gottfried Haberler (1970, s. 115-116) podczas rozważań nad kryzysami walutowymi w latach 60 . stwierdził, że sztywne kursy walutowe rozprzestrzeniają presję inflacyjną i deflacyjną z jednego kraju na pozostałe, więc na OOW presje inflacyjne nie powinny być różnego rodzaju i wielkości, ponieważ utrudni to znacznie walkę z kryzysami. Z kolei Marcus J. Fleming (1971) dodał, że kiedy stopa inflacji w krajach OOW pozostaje na podobnie niskim poziomie, to terms of trade pozostaną analogicznie stabilne. To z kolei będzie sprzyjać zrównoważeniu rachunku obrotów bieżących i handlowi pomiędzy krajami oraz zredukuje potrzebę dostosowywania się nominalnych kursów walutowych. Podobnej stopy inflacji w krajach 
obszaru walutowego można oczekiwać w przypadku: podobnej polityki monetarnej, podobnego celu wielkości zatrudnienia, podobnej stopy produktywności oraz podobnej skali presji związków zawodowych (Fleming, 1971).

Rolę woli politycznej integracji jako warunku powodzenia w procesie przyjęcia wspólnej waluty wskazał natomiast Norman Nelson Mintz (1970). Według niego wola polityczna determinuje kooperację w zakresie polityki ekonomicznej oraz powiązań instytucjonalnych. Z kolei Edward Tower i Thomas Dunaway Willett (1976) podkreślili, iż przystąpienie do obszaru walutowego ograniczy możliwość używania przez kraj przystępujący polityki ekonomicznej w osiąganiu równowagi wewnętrznej, więc należy indywidualnie dla każdego kraju rozpatrywać koszty i korzyści wynikające z tego przystąpienia, biorąc pod uwagę zgodność w preferencjach dotyczących wzrostu gospodarczego, stopy inflacji i bezrobocia. W przypadku zaburzeń równowagi wewnętrznej w kraju obszaru walutowego istotna jest skłonność decydentów politycznych w pozostałych krajach obszaru walutowego do partycypacji w kosztach powrotu do równowagi kraju dotkniętego kryzysem, co jest pochodną stopnia integracji politycznej krajów obszaru walutowego (Tower, Willett, 1976).

Przedstawione kryteria egzogeniczne OOW były przedmiotem debaty od ogłoszenia raportu Wernera do sygnowania traktatu z Maastricht. Wątpliwości dotyczyły sensu tworzenia unii walutowej dla obszaru Europejskiej Wspólnoty Gospodarczej (EWG), ponieważ wykazywano, że zgodnie z tymi kryteriami absorbowanie regionalnych szoków asymetrycznych było efektywniejsze w ramach własnych walut krajów członkowskich. W ramach debaty wykształciły się dwa różne podejścia - ekonomistów reprezentujących podejście egzogeniczne i monetarystów reprezentujących podejście endogeniczne. Ekonomiści egzogeniczni uważali, że unia walutowa w krajach EWG może być zwieńczeniem procesu dostosowań makroekonomicznych zgodnie z kryteriami egzogenicznymi, a finalna konwergencja gospodarcza razem z postanowieniem politycznym stworzy OOW. Natomiast monetaryści twierdzili, iż podjęcie politycznej decyzji o utworzeniu unii walutowej pozwoli na szybsze osiągnięcie konwergencji gospodarczej dzięki wewnętrznym sztywnym kursom walutowym, szczególnie w zakresie konwergencji stopy inflacji i stopy procentowej.

Mundell w 1973 roku zmienił swoje podejście do zagadnienia, argumentując, że ewentualne koszty unii walutowej z powodu braku krajowej polityki monetarnej są mniejsze, niż się zakłada, biorąc pod uwagę ograniczoną efektywność tej polityki $\mathrm{w}$ walce $\mathrm{z}$ międzynarodowym kapitałem spekulacyjnym. Ponadto unia walutowa 
zwiększa możliwości pozyskania kapitału, co z jednej strony zmniejsza prawdopodobieństwo wystąpienia szoku asymetrycznego, a z drugiej strony w przypadku wystąpienia pomaga w walce z jego skutkami (Mundell, 1973b, s. 114-132). Według Mundella krótkoterminowe duże przepływy kapitału są odpowiedzialne za wahania kursowe zakłócające proces optymalnej alokacji. W związku z tym postulował wprowadzenia sztywnych kursów walutowych, co zapewni wspólna waluta, która wyeliminuje niepewność kursów walutowych, zintegruje rynek kapitałowy i zapewni większy podział ryzyka wystąpienia szoku asymetrycznego pomiędzy kraje członkowskie (Mundell, 1973a, s. 143-172).

Dyskurs nurtu endogenicznego rozwinęli Jeffrey Alexander Frankel i Andrew Kenan Rose (1996), wskazując, iż wejście do unii walutowej może wpłynąć na rozwój wymiany handlowej dzięki zniesieniu ryzyka kursowego oraz zmniejszeniu kosztów transakcyjnych, co spowoduje wzajemne dostosowanie się cyklów koniunkturalnych i zredukuje możliwość wystąpienia szoku asymetrycznego, dając w efekcie wypełnienie warunków członkostwa w unii walutowej ex post.

\section{Utworzenie strefy euro w kontekście teorii optymalnego obszaru walutowego}

W 1999 roku Mundell otrzymał nagrodę Banku Szwecji im. Alfreda Nobla w dziedzinie nauk ekonomicznych za analizę polityki monetarnej i fiskalnej w różnych reżimach kursów wymiany oraz analizę OOW. Data otrzymania wyróżnienia nie była przypadkowa, ponieważ 1 stycznia 1999 roku powołano unię walutową na obszarze jedenastu państw europejskich, co mogłoby sugerować znaczący wpływ TOOW na decyzję o utworzeniu strefy euro. Nie potwierdza tego jednak analiza spełniania kryteriów OOW w krajach tworzących unię.

Elastyczność rynków pracy, w tym płac, w krajach tworzących strefę euro była niska. Zgodnie z raportem OECD zmiana realnej płacy w krajach tworzących strefę euro determinowała mniejszy poziom mobilności pracowników w porównaniu do Stanów Zjednoczonych. Istotny wpływ na to miała działalność związków zawodowych, której efektem było usztywnienie płac i cen oraz protekcjonistyczne przepisy prawa pracy. Brak elastyczności cenowej był również wynikiem zaburzenia warunków konkurencji rynkowej wskutek pomocy państwa dla niektórych sektorów gospodarki i tendencji monopolistycznych w sektorach gospodarki z dużą reprezen- 
tacją przedsiębiorstw państwowych. Czynnikami ograniczającymi mobilność pracowników były także: zróżnicowane transfery socjalne, nieuznawanie kwalifikacji zawodowych, bariery językowe, a nawet różnice kulturowe kształtujące styl życia. W poszczególnych krajach strefy euro poziom krajowej migracji nie przekraczał 2\% ogółu populacji, a w krajach peryferyjnych strefy euro, jak Hiszpania czy Włochy, spadał poniżej $1 \%$. Migracja pomiędzy krajami strefy euro nie przekraczała poziomu $0,5 \%$ populacji. Skłonność pracowników na terenie strefy euro do poszukiwania pracy za granicą była niewielka i występowała najczęściej wśród mieszkańców rejonów nadgranicznych. Międzynarodowa mobilność pracowników na terenie unii walutowej była najwyższa wśród zawodów niewymagających wysokich umiejętności posługiwania się językiem właściwym dla miejsca zatrudnienia. Liczba obywateli krajów unii walutowej mieszkających w innym kraju unii wynosiła tylko 1,5\% całej populacji strefy euro i utrzymywała się od lat na stałym poziomie (OECD, 1999, s. 117-195). Patrick Puhani (1999) wykazał, że w Niemczech w porównaniu z innymi krajami strefy euro mobilność pracowników była relatywnie wysoka, lecz nawet tam przystosowanie się do szoku asymetrycznego wymagało kilku lat. W związku z tym stwierdził, iż mobilność pracowników w strefie euro nie była skutecznym środkiem absorbującym skutki szoków asymetrycznych.

Stopień otwartości gospodarek strefy euro mierzony stosunkiem wartości handlu zagranicznego do PKB w 1999 roku był według danych OECD większy niż $40 \%$ dla wszystkich krajów unii walutowej, czyli na wysokim poziomie (Mongelli, 2002).

Integracja fiskalna pomiędzy krajami unii walutowej może być oceniana w różny sposób. Niewątpliwie nastąpiła konwergencja fiskalna dzięki dostosowaniu się do kryteriów fiskalnych traktatu z Maastricht, czyli maksymalny deficyt budżetowy na poziomie 3\% PKB oraz maksymalne zadłużenie publiczne na poziomie $60 \%$ PKB. Pakt Stabilności i Wzrostu pogłębił wymagania dotyczące polityki fiskalnej W strefie euro, wprowadzając reguły nadzoru budżetowego i procedurę nadmiernego deficytu, oraz obligował państwa unii walutowej do osiągania nadwyżki budżetowej w okresie dobrej koniunktury. Wprowadzone kary za nieprzestrzeganie procedur, niestety, nie były automatyczne, o co zabiegali Hans Tietmeyer i Otmar Issing. Integracja fiskalna pogłębiała się również dzięki postępom w ujednoliceniu prawa podatkowego. Jednak polityka fiskalna pozostawała ciągle jeszcze domeną suwerennych rządów krajów członkowskich strefy euro, co skutkowało brakiem rozwiązań 
uwzględniających wyzwania przedstawione w TOOW, czyli utworzenia instytucji ponadnarodowej dysponującej własnym budżetem, która mogłaby stabilizować obszary dotknięte szokiem asymetrycznym poprzez autonomiczne decyzje dotyczące redukcji obciążeń fiskalnych i transferów środków budżetowych (Mongelli, 2002).

Poziom dywersyfikacji i podobieństwa strukturalnego gospodarek dzielił powstałą unię walutową na dwie strefy: strefę krajów centralnych, jak Niemcy, Francja, Holandia, Belgia, Austria, Luksemburg i Finlandia, oraz strefę krajów peryferyjnych, jak Irlandia, Włochy, Hiszpania i Portugalia. Gospodarki krajów centralnych charakteryzowały się wyższym poziomem innowacji, dywersyfikacji produkcji oraz zastosowaniem zaawansowanych technologii, co przekładało się na przewagę konkurencyjną i niższe nominalne jednostkowe koszty pracy (Botta, 2014).

Kryterium stabilności cen z traktatu z Maastricht wprowadzało obowiązek dostosowania stopy inflacji państwa do poziomu nieprzekraczającego o więcej niż 1,5 punktu procentowego stopy inflacji trzech państw Unii Europejskiej o najniższym poziomie inflacji. Zgodnie z raportem Komisji Europejskiej dotyczącym konwergencji z 1998 roku w krajach przystępujących do unii walutowej udało się spełnić to kryterium (European Commission, 1998, s. 60-76). Nominalny poziom dostosowania stóp inflacji osiągnięto dzięki doraźnemu stosowaniu narzędzi polityki ekonomicznej. W raporcie tym wskazywano jednak na koszt osiągnięcia tego sukcesu w postaci spowolnienia wzrostu gospodarczego. Zróżnicowana konkurencyjność gospodarek unii walutowej pozostawała potencjalną przyczyną powstawania presji inflacyjnej (European Commission, 1998, s. 168-170).

Integracja rynków finansowych pogłębiała się wraz z implementacją zasady swobodnego przepływu kapitału w krajach Unii Europejskiej. Integracja rynku kapitałowego dawała większą możliwość inwestowania, większą płynność rynku, zmniejszała koszt kapitału i usług finansowych dzięki zwiększonej konkurencji na zintegrowanym rynku. Integracja rynku kredytowego i papierów dłużnych doprowadziła do obniżenia nominalnej stopy procentowej i ułatwiła dostęp do kapitału, szczególnie w krajach peryferyjnych, jak Portugalia, Hiszpania i Włochy. W związku z tym wskazywano na możliwość zagrożenia systemowego na rynku bankowym na terenie unii walutowej wskutek zwiększonej akcji kredytowej i współdzielenia ryzyka. Powiązania kapitałowe na rynku międzybankowym były coraz mocniejsze i tworzyły system naczyń połączonych, który w przypadku ewentualnego kryzysu mógłby go szybko rozprzestrzenić (Schüler, 2002). 
Reimut Jochimsen (1994, s. 58) słusznie zauważył, iż z perspektywy historycznej nie ma przykładu trwałej unii walutowej bez unii politycznej. Wspólną walutę utworzyło kilkanaście suwerennych państw niemających zamiaru zjednoczenia się w jeden organizm państwowy. Polityczna integracja wśród członków unii walutowej dokonywała się za pomocą instytucji Unii Europejskiej. Na poziom ponadnarodowy nie przeniesiono jednak kompetencji decyzyjnych państw narodowych w zakresie polityki ekonomicznej odpowiedzialnej za redystrybucję i alokację środków, co utrudniało szybką reakcję na wystąpienie szoków asymetrycznych.

\section{Podsumowanie}

Przedstawiona analiza wymagań wynikających z TOOW oraz faktów charakteryzujących sytuację w krajach, które utworzyły unię walutową w 1999 roku, wskazuje, że kraje te nie spełniały kryteriów OOW. Issing (2005), członek zarządu Europejskiego Banku Centralnego w latach 1998-2006, odniósł się do omawianego problemu w następujących słowach:

Przed stworzeniem europejskiej unii walutowej pomysł wspólnej polityki pieniężnej dla krajów strefy euro spotkał się ze sceptycyzmem wśród ekonomistów popartym argumentami teorii optymalnego obszaru walutowego, która rekomendowała zdecydowane usztywnienie kursu walutowego wśród gospodarek z elastycznymi rynkami, swobodnym przepływem czynników produkcji i ograniczonej skłonności do występowania szoków asymetrycznych. Z pewnością to nie jest strefa euro, która charakteryzuje się wyją̧tkowymi cechami instytucjonalnymi i ekonomicznymi, takimi jak znaczna sztywność rynków pracy, ograniczona mobilność pracowników, zróżnicowane krajowe struktury przemysłu, różna stopa wzrostu wydajności, brak znaczącego scentralizowanego mechanizmu transferów socjalnych i zdecentralizowana odpowiedzialność za politykę fiskalną i inne polityki ekonomiczne. W tych okolicznościach szoki asymetryczne, a nawet typowe szoki makroekonomiczne z pewnością wywołają inflację. Często argumentuje się, że wspólna polityka monetarna implementująca jednakową wysokość stopy procentowej wespół ze zróżnicowanymi terytorialnie tendencjami do indukowania presji inflacyjnej na obszarze unii walutowej prowadzi do odmiennych realnych stóp procentowych w różnych krajach. To może destabilizować unię walutową przez przyczynianie się do generowania inflacji. 
W projekcie politycznym europejskiej unii walutowej nie wdrożono reform wychodzących naprzeciw wymaganiom TOOW. Konieczne zmiany odłożono ad Kalendas Graecas, co wzmacniało sceptycyzm wielu ekonomistów odnośnie do powodzenia tej inicjatywy politycznej. Jednak cel polityczny utworzenia europejskiej unii walutowej był dla decydentów ważniejszy od ryzyka ekonomicznego, które w pewien sposób ziściło się podczas ostatniego globalnego kryzysu i miało swoje daleko idące konsekwencje dla strefy euro i całej Unii Europejskiej. Kryzys ten ujawnił instytucjonalną słabość oraz niski stopień spójności krajów w strefie euro. Wykazał także, że słaba konwergencja gospodarek należących do tej strefy uniemożliwia prowadzenie wspólnej polityki korzystnej dla każdego z jej członków. Zasadniczym problemem przyszłościowym, mogącym mieć dalsze negatywne konsekwencje, jest fakt, że gospodarki tworzące strefę euro długo jeszcze nie będą spełniały warunków zgodnych z założeniami TOOW, niezbędnych do funkcjonowania wspólnej waluty.

\section{Literatura}

Botta, A. (2014). Structural Asymmetries at the Roots of the Eurozone Crisis: What's New for Industrial Policy in the EU? Levy Economics Institute Working Paper, 794, 2-29.

European Commission (1998). European Economy, 65. Pobrano z: http://ec.europa.eu/ economy_finance/publications/publication8013_en.pdf (20.12.2015).

Fleming, M.J. (1971). On Exchange Rate Unification. The Economic Journal, 81 (323), $467-488$.

Frankel, J.A., Rose, A.K. (1996). Endogeneity of the Optimum Currency Area Criteria. The Centre for Economic Policy Research Discussion Paper, 1473, 1-37.

Haberler, G. (1970). The International Monetary System: Some Recent Developments and Discussions. W: G.H. Halm (red.), Approaches to Greater Flexibility of Exchange Rates (s. 115-123). Princeton: Princeton University Press.

Ingram, J.C. (1962). A Proposal for Financial Integration in the Atlantic Community. W: Joint Economic Committee, Factors Affecting the United States Balance of Payments (s. 177-207). Washington: Government Press Office.

Ingram, J.C. (1969). Comment: The Currency Area Problem. W: R.A. Mundell, A.L. Swoboda (red.), Monetary Problems of the International Economy (s. 95-100). Chicago: The University of Chicago Press. 
Issing, O. (2005). One Size Fits All! A Single Monetary Policy for the Euro Area. Speech to the International Research Forum. Pobrano z: http://www.ecb.int/press/key/date/2005/ html/sp050520.en.html (21.12.2015).

Jochimsen, R. (1994). Perspektiven der europaeischen Wirtschafts- und Waehrungsunion. Kolonia: Nomos Verlag.

Kennen, P.B. (1969). The Theory of Optimum Currency Areas: an Eclectic View. W: R.A. Mundell, A.L. Swoboda (red.), Monetary Problems of the International Economy (s. 41-60). Chicago: University of Chicago Press.

McKinnon, R.I. (1963). Optimum Currency Area. The American Economic Review, 53 (4), $717-725$.

Mintz, N.N. (1970). Monetary Union and Economic Integration. The Bulletin of New York University Graduate School of Business Administration (Institute of Finance), 64, $1-36$.

Mongelli, F.P. (2002). „New” Views on the Optimum Currency Area Theory: What is EMU telling us? European Central Bank Working Paper, 138, 1-54.

Mundell, R.A. (1961). A Theory of Optimum Currency Areas. The American Economic Review, 51 (4), 657-665.

Mundell, R.A. (1973a). A Plan for a European Currency. W: H.G. Johnson, A.K. Swoboda (red.), The Economics of Common Currencies (s. 143-172). London: George Allen \& Unwin Ltd.

Mundell, R.A. (1973b). Uncommon Arguments for Common Currencies.W: H.G. Johnson, A.K. Swoboda (red.), The Economics of Common Currencies (s. 114-132). London: George Allen \& Unwin Ltd.

OECD (1999). EMU Facts, Challenges and Policies. Paris.

Puhani, P.A. (1999). Labour Mobility - An Adjustment Mechanism in Euroland? Empirical Evidence for Western Germany, France and Italy. German Economic Review, 2 (2), $127-140$.

Schüler, M. (2002). The Threat of Systemic Risk in Banking - Evidence for Europe. Centre for European Economic Research Discussion Paper, 21, 1-32.

Tower, E., Willett, T.D. (1976). The Theory of Optimum Currency Areas and Exchange Rate Flexibility: A More General Framework. Special Papers in International Economics (Princeton University), 11, 1-98. 


\title{
THE CREATION OF THE EUROPEAN MONETARY UNION AS AN OPTIMUM CURRENCY AREA
}

\begin{abstract}
The paper presents the circumstances of the creation and the development of the theory of optimum currency area (OCA) and its economical criterias, which shall be implemented in such area. The main point of the paper is an attempt of the adaptation analysis of achievements in economics in subject of optimum currency area during realization of the plans concerning the creation of the monetary union in Europe, established in 1999. The results of this analysis suggests that the reason of the creation of the European monetary union was political will, not the economic circumstances.
\end{abstract}

Translated by Krzysztof Kielec

Keywords: optimum currency area, criterias, eurozone JEL Codes: F15, F45 